\title{
Perbadingan Daya Hambat Ekstrak Rimpang Temu Putri (Curcuma petiolata Roxb) terhadap Staphylococcus aureus dan Eschericia coli
}

\section{Inhibitory Comparison of Extract Rhizome of Temu Putri (Curcuma petiolata Roxb) on Staphylococcus aureus and Escherichia coli}

\author{
Abdul Wahid \\ Jurusan Farmasi, Fakultas Farmasi, Universitas Megarezky Makassar \\ Jl. Antang Raya No. 43 Makassar \\ Email : wahid26061991@gmail.com/085346587599
}

Submitted : 6 Juni 2020 Reviewed : 26 Juli 2020 Accepted : 27 Agustus 2020

\begin{abstract}
Abstrak
Tanaman Temu Putri (Curcuma petiolata Roxb) merupakan tanaman asli Indonesia yang sering dimanfaatkan masyarakat sebagai obat tradisonal yang memiliki kaya akan manfaat bagi kesehatan dan bagian yang paling sering digunakan sebagai obat adalah rimpang . Penelitan ini bertujuan untuk menentukan dan membandingkan daya hambat ekstrak Rimpang Temu Putri terhadap Staphylococcus aureus dan Eschericia coli. Penelitian ini dilakukan dengan menggunakan metode disk diffusion (Test Kirby dan Bauer). Dari hasil penelitian ini diperoleh data yang menunjukkan bahwa Pemberian ekstrak Rimpang Temu Putri pada kosentrasi $1 \%, 2 \%$ dan $3 \%$ b/v menunjukkan efek antibakteri terhadap Staphylococcus aureus dan Eschericia coli. Konsentrasi 3\% b/v menunjukkan efek yang paling baik terhadap pertumbuhan Staphylococcus aureus dan Eschericia coli. Hasil analisis uji ANOVA menunjukkan ekstrak Rimpang Temu Putri memilki perbedaaan daya hambat yang signifikan $(\mathrm{p}<0,05)$ terhadap pertumbuhan Staphylococcus aureus dan Eschericia coli. Ekstrak Rimpang Temu Putri paling efektif menghambat Staphylococcus aureus dibandingkan Eschericia coli.
\end{abstract}

Kata kunci : Daya Hambat, Staphylococcus aureus, Eschericia coli, Rimpang Temu Putri

\begin{abstract}
The Temu Putri Plant (Curcuma petiolata Roxb) is a native plant of Indonesia that is often used by the community as a traditional medicine that has rich health benefits and the part most often used as medicine is the rhizome. This research aims to determine and compare the inhibitory properties of the Temu Putri Rhizome extract on Staphylococcus aureus and Eschericia coli. This research was conducted using the disk diffusion method (Kirby and Bauer Test). From the results of this study obtained data that showed that the administration of Temu Putri Rhizome extract at a concentration of $1 \%, 2 \%$ and $3 \% \mathrm{w} / \mathrm{v}$ showed an antibacterial effect on Staphylococcus aureus and Eschericia coli. Concentration of $3 \% \mathrm{w} / \mathrm{v}$ showed the best effect on the growth of Staphylococcus aureus and Eschericia coli. The results of the ANOVA analysis showed Temu Putri Rhizome extract had a significant inhibition difference $(\mathrm{p}<0.05)$ to the growth of Staphylococcus aureus and Eschericia coli. The Temu Putri Rhizome Extract is the most effective in inhibiting Staphylococcus aureus compared to Eschericia coli.
\end{abstract}


Keywords : The Power Test Inhibitory, Temu Putri, Staphylococcus aureus, Eschericia coli

\author{
Penulis Korespondensi : \\ Abdul Wahid \\ Jurusan Farmasi, Fakultas Farmasi, Universitas Megarezky Makassar \\ Jl. Antang Raya No. 43 Makassar \\ Email: wahid26061991@gmail.com/085346587599
}

\title{
PENDAHULUAN
}

Pengobatan tradisional sudah ada di Indonesia sejak ribuan tahun yang lalu dan jauh sebelum pelayanan kesehatan modern dikenal di masyarakat. Pengobatan ini dimanfaatkan oleh manusia dalam pengobatan segala penyakit dan sekarang sudah dimanfaatkan dan diakui masyarakat dunia (Wijayakusuma, 2012). Selain itu, pengobatan tradisional meruakan pengobatan yang minim efek samping dan biaya pengobatannya relative murah sehingga lebih terjangkau bagi masyarakat secara luas.

Banyak tanaman di Indonesia yang belum di eksplorasi secara luas yang dapat dijadikan sebagai obat tradisonal, salah satunya adalah Tanaman Temu Putri (Curcuma petiolata Roxb). Temu putri merupakan terna tahunan yang tumbuh tegak.Tanaman ini biasa digunakan sebagai obat dan kosmetik, cukup baik juga ditanam sebagai tanaman hias karena bentuknya yang eksotik (Dhalimartha, 2012). Tanaman ini juga merupakan salah satu jenis tumbuhan asli Indonesia yang sangat banyak manfaatnya dan sering digunakan sebagai jamu untuk mengobati demam, penambah nafsu makan, radang empedu, radang ginjal, antikanker, batu empedu, alergi dan diare. Bagian tanaman biasa digunakan yaitu rimpang (Achmad et al., 2008, Suthiwong et al., 2014).

Mikroba atau mikoroorganisme adalah organisme hidup berukuran sangat kecil yang tidak dapat terlihat oleh mata yang dapat bersifat patogen atau dapat menimbulkan berbagai macam penyakit. Contoh mikroorganisme patogen adalah Staphylococcus aureus dan Escherichia coli (Pratiwi, 2010). Penelitian sebelumnya melaporkan bahwa Curcuma petiolata mengandung senyawa sesquiterpene yang dapat bertindak sebagai antibakteri (Sun, et al., 2017, Diastuti, et al., 2016).

Berdasarkan hal tersebut diatas, maka tanaman temu putri berpotensi sebagai antibakteri. Tujuan dari penelitian ini adalah untuk menentukan dan membandingkan daya hambat ekstrak rimpang temu putri terhadap Staphylococcus aureus dan Eschericia coli. Hasil penelitian ini diharapkan dapat menjadi informasi tambahan tentang aktivitas antibakteri dari tanaman Temu Putri.

\section{METODE PENELITIAN}

\section{Alat dan Bahan}

Alat yang digunakan adalah Autoklaf, Bunsen, cawan petri, erlemeyer, gelas ukur, gelas kimia, Inkubator, kain flanel, labu ukur, ose bulat/lurus, oven, rotavapor, spoit $1 \mathrm{ml}$, spoit $5 \mathrm{ml}$, spoit $20 \mathrm{ml}$, labu alas bulat, timbangan analitik dan toples maserasi.

Bahan yang digunakan Aquadest, Aluminium Foil, biakan Escherichia coli, biakan Staphylococcus aureus, Rimpang temu putri, Etanol 96\%, Kapas, Korek api, Label, medium Nutrien Agar (NA), Paper disc, Tetrasiklin $\mathrm{HCl}$. 


\section{Jalannya Penelitian}

1. Pembuatan Ekstrak Etanol Rimpang Temu Putri

Bahan Uji Rimpang Temu Putri yang telah dikeringkan kemudian, ditimbang 250 gram dan diekstraksi menggunakan metode maserasi dengan cara merendam sampel dengan etanol $96 \%$ sebanyak $1875 \mathrm{ml}$, kemudian tutup dan simpan selama 5 hari sambil sesekali diaduk selanjutnya disaring. Ampasnya dimasukan kembali ke dalam alat maserasi dan dilakukan seperti semula sampai cairan penyari tak berwarna atau di ulangi hingga 3 kali. Hasil ekstraksi dipekatkan dengan rotavapor kemudian diuapkan di atas penangas air hingga diperoleh ekstrak kental.

2. Pembuatan Media Nutrien Agar (NA)

Ditimbang 2,3 gram Medium Nutrien Agar dan dimasukkan kedalam Erlenmeyer lalu dilarutkan dengan air suling sedikit demi sedikit dibantu dengan sedikit pemanasan agar semua bahan larut, diatur pada $\mathrm{pH}$ 7,0 dan dicukupkan volumenya dengan air suling 100 $\mathrm{ml}$ disterilkan dalam autoklaf pada suhu $121^{\circ} \mathrm{C}$ selama 15 menit dengan tekanan 1 atmosfir.

3. Pembuatan larutan kontrol positif Tetrasiklin $\mathrm{HCl} 30 \mathrm{bpj}$

Ditimbang $50 \mathrm{mg}$ Tetrasiklin $\mathrm{HCl}$ dan dilarutkan dengan $100 \mathrm{ml}$ air suling (500 bpj) sebagai larutan stok I. Dipipet $2 \mathrm{ml}$ larutan stok I dan dicukupkan volumenya hingga 10 $\mathrm{ml}$ (100 bpj) sebagai larutan stok II. Dipipet $3 \mathrm{ml}$ larutan stok II dan dicukupkan volumenya hingga $10 \mathrm{ml}(30 \mathrm{bpj})$.

4. Pembuatan larutan uji

Ekstrak Rimpang Temu Putri dibuat dengan variasi konsentrasi yaitu 1\%b/v, 2\%b/v dan $3 \% \mathrm{~b} / \mathrm{v}$ dengan cara di timbang sebanyak 0,5 gram, disuspensikan dengan air suling steril hingga $50 \mathrm{ml}$ di dapatkanlah konsentrasi ekstrak $1 \% \mathrm{~b} / \mathrm{v}$, pembuatan ekstrak dengan konsentrasi $2 \% \mathrm{~b} / \mathrm{v}$, dan $3 \% \mathrm{~b} / \mathrm{v}$ digunakan cara yang sama dimana ekstrak kering Rimpang temu putri ditimbang masing-masing sebanyak 1 gram, dan 1,5 gram.

5. Pengujian aktivitas antibakteri

Ekstrak etanol Rimpang Temu Putri dibuat dengan variasi konsentrasi yaitu 1\%b/v, 2\%b/v dan 3\%b/v. Media Nutrien Agar dituang secara aseptis kedalam masing-masing cawan petri sebanyak $15 \mathrm{ml}$ setelah memadat diambil masing-masing suspensi bakteri Staphylococcus aureus dan Escherichia coli dengan menggunakan swab steril. Diinokulasikan secara merata pada medium yang telah memadat. Kemudian dilanjutkan dengan meletakkan paperdisck yang telah direndam larutan ekstrak konsentrasi $1 \% \mathrm{~b} / \mathrm{v}$, $2 \% \mathrm{~b} / \mathrm{v}, 3 \% \mathrm{~b} / \mathrm{v}$ sampel uji ekstrak Rimpang Temu Putri, kontrol negatif menggunakan aquadest dan kontrol positif Tetrasilkiln menggunakan pinset steril dengan jarak $2-3 \mathrm{~cm}$ pada pinggir cawan petri. Diinkubasi pada suhu $37^{\circ} \mathrm{C}$ selama 1 x 24 jam. Daerah hambatan yang terbentuk di ukur dengan mistar sorong. Perlakuan ini dilakukan sebanyak 3 kali dan diambil rata-ratanya.

\section{Analisis Data}

Metode analisis data yang digunakan adalah metode ekssperimental yaitu berupa data kuantitatif. Data disajikan dalam bentuk tabel dan gambar.

\section{HASIL DAN PEMBAHASAN}

Hasil pengukuran diameter zona hambatan (mm) Ekstrak Rimpang Temu Putri (Curcuma petiolata Roxb) Terhadap Staphylococcus aureus dan Eschericia coli. 
Table 1 : Hasil Pengukuran Diameter Zona Hambat Ekstrak Rimpang Temu Putri Terhadap Staphylococcus aureus dan Eschericia coli.

\begin{tabular}{cccccc}
\hline \multirow{2}{*}{ Bakteri uji } & \multicolumn{5}{c}{ Diameter Zona Hambatan (mm) } \\
\cline { 2 - 6 } & A & B & C & D & E \\
\hline \multirow{2}{*}{ Staphylococcus aureus } & 6 & 10,45 & 11,95 & 13,15 & 20,25 \\
& 6 & 11,00 & 12,25 & 13,65 & 19,02 \\
& 6 & 11,25 & 12,85 & 14,00 & 19,25 \\
Eschericia coli & 6 & 9,25 & 10,95 & 13,05 & 17,50 \\
& 6 & 9,75 & 11,50 & 13,25 & 19,25 \\
& 6 & 10,25 & 12,50 & 13,75 & 20,12
\end{tabular}

Keterangan :
A $=$ Aquadest
$\mathrm{B}=$ Ekstrak Rimpang Temu Putri $1 \% \mathrm{~b} / \mathrm{v}$
$\mathrm{C}=$ Ekstrak Rimpang Temu Putri $2 \% \mathrm{~b} / \mathrm{v}$
$\mathrm{D}=$ Ekstrak Rimpang Temu Putri $3 \% \mathrm{~b} / \mathrm{v}$
$\mathrm{E}=$ Tetrasiklin

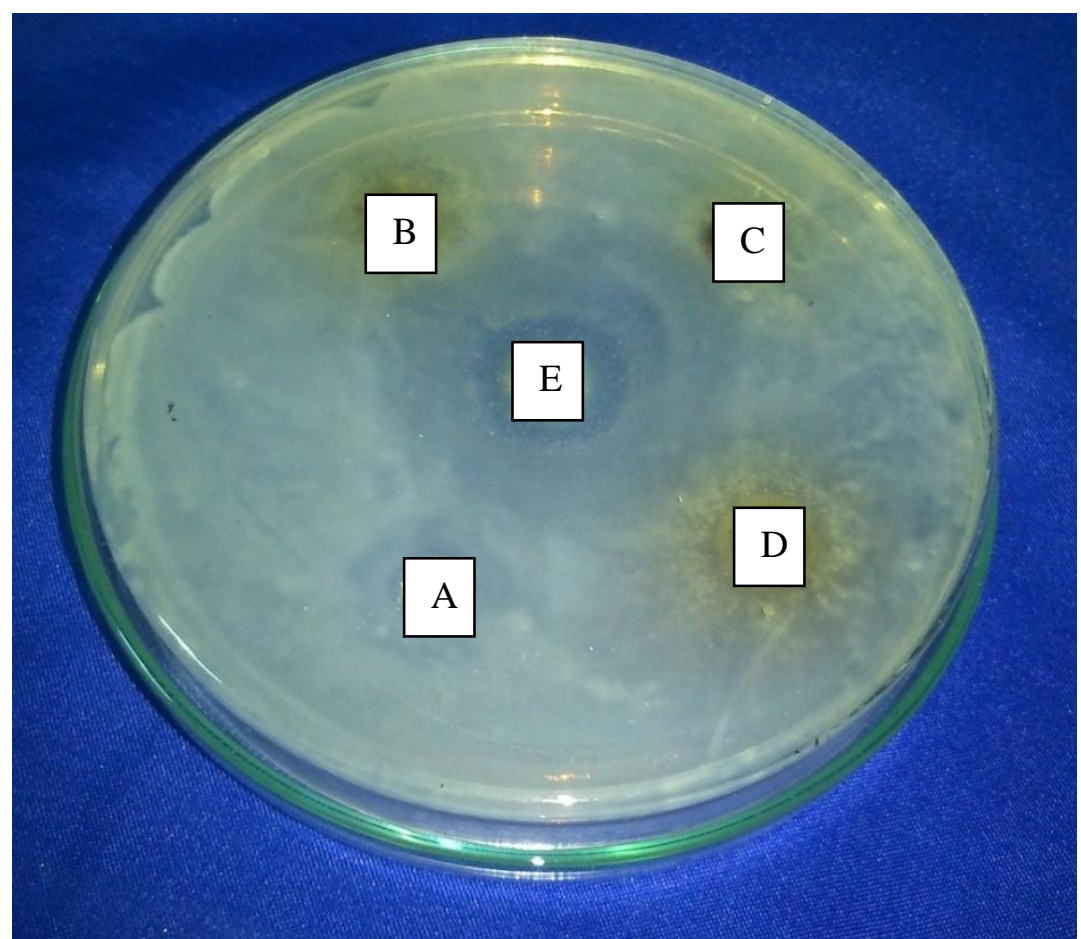

Gambar 1 . Hasil Pengamatan Daerah Zona hambatan Ekstrak Rimpang Temu Putri (Curcuma petiolata Roxb)Terhadap Pertumbuhan Staphylococcus aureus 


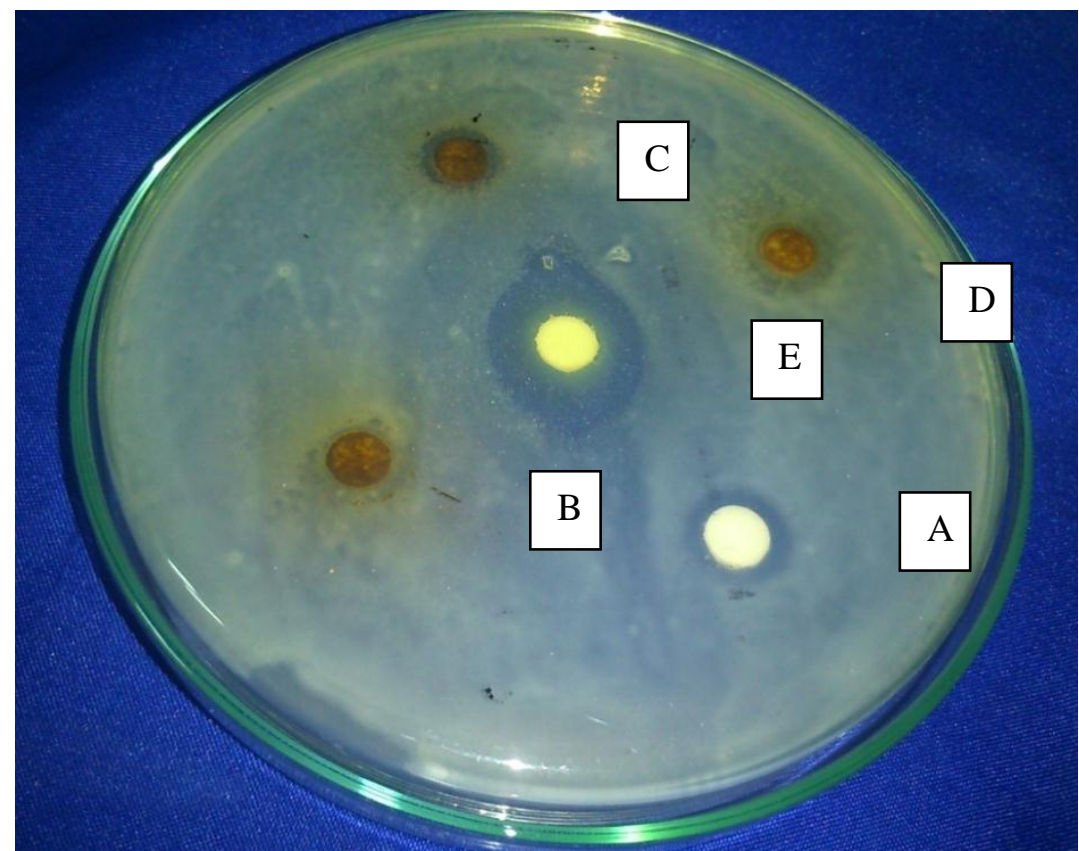

Gambar 2 . Hasil Pengamatan Daerah Zona hambatan Ekstrak Rimpang Temu Putri (Curcuma petiolata Roxb)Terhadap Pertumbuhan Eschericia coli

Keterangan :
A $=$ Aquadest
$\mathrm{B}=$ Ekstrak Rimpang Temu Putri $1 \% \mathrm{~b} / \mathrm{v}$
$\mathrm{C}=$ Ekstrak Rimpang Temu Putri $2 \% \mathrm{~b} / \mathrm{v}$
$\mathrm{D}=$ Ekstrak Rimpang Temu Putri 3\% b/v
$\mathrm{E}=$ Tetrasiklin

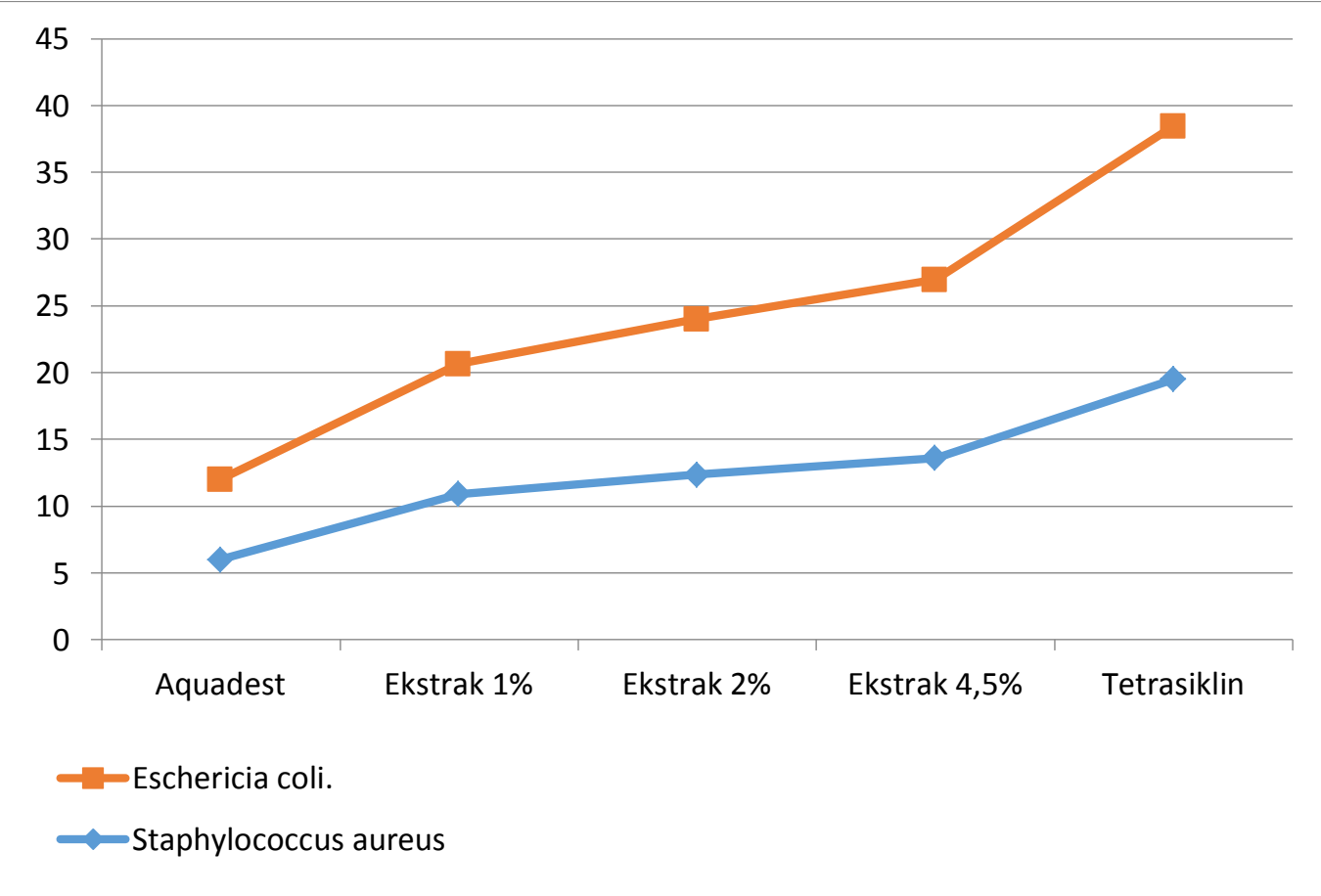

Gambar 3. Diameter zona hambatan $(\mathrm{mm})$ pemberian ekstrak Rimpang temu putri terhadap Staphylococcus aureusdan Eschericia coli 
Pada penelitian ini tentang Uji Daya Hambat Ekstrak Rimpang Temu Putri (Curcuma petiolata Roxb) terhadap Staphylococcus aureus dan Eschericia coli. Pengujian efek antibakteri dilakukan dengan menggunakan metode difusi disk diffusion (Test Kirby dan Bauer). Sebelum dilakukan pengujian, terlebih dahulu bakteri diinokulasi pada media agar miring NA dalam tabung reaksi. Inokulasi dimaksudkan untuk meremajakan kultur bakteri murni supaya pertumbuhan dalam media. Aquadest sebagai kontrol negatif merupakan pensuspensi yang diketahui tidak memiliki aktivitas antibakteri digunakan untuk melihat apakah zona hambat yang terjadi benar-benar berasal dari sampel dan bukan disebabkan oleh faktor teknis perlakuan.

Pada metode disk diffusion ini menggunakan paper disk yang diletakkan pada medium Nutrien Agar (NA) yang telah dicelupkan kedalam ekstrak Rimpang Temu Putri dengan konsentrasi $1 \%, 2 \%$ dan $3 \% \mathrm{~b} / \mathrm{v}$, kontrol negatif serta pemberian tetrasiklin sebagai pembanding.

Tetrasiklin digunakan karena Antibiotik ini mampu bekerja menghambat dan membunuh bakteri gram positif dan negativ sehingga cocok untuk digunakan sebagai kontrol dalam penelitian ini karena bakteri uji yang dilakukan adalah bakteri gram positif dan negativ.

Metode disk diffusion dilakukan untuk mengetahui besarnya diameter zona hambat yang terbentuk terhadap Staphylococcus aureus dan Eschericia coli setelah inkubasi pada suhu $37^{\circ} \mathrm{C}$ selama 1 x 24 jam. Ekstrak Rimpang Temu Putri akan berdifusi keluar untuk menghambat pertumbuhan bakteri pada medium yang ditunjukan dengan adanya zona hambat yang terbentuk pada medium disekeliling paper disk, ditandai dengan adanya daerah bening, zona hambat yang terbentuk inilah yang kemudian diukur.

Tanaman temu putri berkhasiat sebagai melancarkan sistem pencernaan, Membersihkan darah wanita yang baru melahirkan. Obat penurun panas / demam, mencegah infeksi, mengobati sakit perut, penambah selera makan, dan juga mampu menenangkan syaraf sehingga mencegah stress dan lain-lainnya (Versteegh J.K. 2012)

Berdasarkah hasil penelitian yang telah dilakukan menunjukkan bahwa zona hambat pemberian ekstrak Rimpang Temu Putri dengan konsentrasi 1\%, 2\% dan 3\% b/v, tetrasiklin dan Aquadest sebagai pembanding memiliki daerah zona hambatan terhadap pertumbuhan Staphylococcus aureus masing-masing 10,9 mm, 12,35 mm, 13,6 mm 19,50 mm dan $6 \mathrm{~mm}$. Sedangkan zona hambatan terhadap Eschericia coli masing-masing 9,75 mm, 11,65 mm, $13,35 \mathrm{~mm}, 18,95 \mathrm{~mm}$ dan $6 \mathrm{~mm}$. Hal ini menunjukkan bahwa konsentrasi yang lebih tinggi memberikan daya hambat yang lebih besar.

Kemampuan senyawa antibakteri dalam membunuh dan menghambat pertumbuhan mikroorganisme itu tergantung dari konsentrasi bahan dari senyawa antibakteri tersebut. Hal ini menunjukkan bahwa semakin tinggi konsentrasi semakin besar pula aktivitas antibakteri yang diberikan. Menurut Ajizah (2004) selain konsetrasi yang dapat mempengaruhi aktivitas antibakteri, jenis bahan atau pemilihan bahan juga mempengaruhi kandungan kimia yang ada dalam bahan tersebut dalam menentukan antivitas antibakteri.

Adapun kandungan kimia dari Rimpang Temu Putri yang berkhasiat sebagai antibakteri yaitu senyawa terpen (sesquiterpene). Mekanisme kerja sesquiterpene dalam menghambat bakteri dengan cara senyawa ini membentuk lipofilis atau larut dalam lemak dan lipid sehingga dapat mempermudah menembus dinding sel dan menganggu fungsi membran sel bekteri (Simoes et al., 2009; Saleem et al, 2010). .

Hasil analisis uji ANOVA menunjukkan ekstrak Rimpang Temu Putri memiliki perbedaaan daya hambat yang signifikan $(\mathrm{p}<0,05)$ terhadap pertumbuhan Staphylococcus aureus dan Eschericia coli. Hal ini terlihat pada tabel 1 memperlihatkan hasil daya hambat yang berbeda dari setiap konsentrasinya. Semakin tinggi konsentrasinya semakin besar pula daya hambanya. Diketahui rata-rata yang paling tinggi terlihat masing-masingg pada konsentrasi 3\% yaitu 13,60 mm terhadap Staphylococcus aureus dan 13,35 mm terhadap Eschericia coli. Hasil ini juga menujukkan bahwa Ekstrak Rimpang Temu Putri dapat bertindak sebagai antibakteri dan paling efektif menghambat Staphylococcus aureus dibandingkan Eschericia coli. 


\section{KESIMPULAN}

Pemberian ekstrak Rimpang Temu Putri pada kosentrasi 1\%, 2\% dan 3\% b/v menunjukkan efek antibakteri terhadap Staphylococcus aureus dan Eschericia coli. Konsentrasi $3 \%$ b/v menunjukkan efek yang paling baik terhadap pertumbuhan Staphylococcus aureus dan Eschericia coli, tetapi potensinya masih lebih rendah dibandingkan pemberian tetrasiklin sebagai kontrol positif.

\section{DAFTAR PUSTAKA}

Achmad, S.A., Hakim, E.H., Makmur, L., Syah, Y.M., Juliawaty, L.D., and Mujahidin, D., 2008. Ilmu Kimia dan Kegunaan Tumbuh-tumbuhan Obat Indonesia. Jilid 1. Penerbit ITB, Bandung. 132-149

Ajizah, A. 2004. Sensitivitas Salmonella typhimurium terhadap ekstrak daun Psidium guajava . J Bioscientiae. 1(1):31-38.

Dhalimartha, S., 2012, Atlas Tumbuhan Obat Indonesia Jilid 6 Revisi, Pustaka Bunda.

Departemen Kesehatan Republik Indonesia, 1986, Sediaan Galenik, Direktorat Jenderal Pengawasan Obat dan Makanan, Jakarta.

Departemen Kesehatan Republik Indonesia, 1995, Farmakope Indonesia, Edisi IV, Direktorat Jenderal Pengawasan Obat dan Makanan, Jakarta.

Djide, M. N, 2009, Mikrobiologi Farmasi, Universitas Hasanuddin, Makassar.

Hariana A.H, 2013, Tumbuhan Obat dan Khasiatnya.,Seri III, Penerbit Penebar Swadaya, Jakarta

Pratiwi.S, 2010, Mikrobiologi Farmasi, PT Erlangga, Jakarta.

Sartono, R, 2011,Perawatan Tubuh dan Pengobatan -pengobatan Tradisional. Effhar dan Dahara Prize, Semarang

Sari, S,P,W. 2014. Penelusuran Potensi Kapulaga, Temu Putri dan Senggugu sebagai Penghambat Pembentukan Biofilm.Laboratorium Fitokimia, Fakultas Farmasi, Universitas Gadjah Mada, Sekip Utara, Yogyakarta

Saleem, M., Nazir, M., Ali, M.S., Hussain, H., Lee, Y. S., Riaz, N., and Jabbar, A., 2010. Antimicrobial Natural Products: An Update on Future Antibiotic Drug Candidates.

Natural Product Report 27, 238-254

Suthiwong, J., Pitchuanchom, S., Wattanawongdon, W., Hahnvajanawong, C. and Yenjai, C. (2014). Isolation, docking and cytotoxicity evaluation against cholangiocarcinoma of labdanes from Curcuma petiolata. Asian J. Chem. 26(14):4286-4290

Simoes, M., Bennet, R.N., and Rosa, E.A.S., 2009. Understanding Antimicrobial Activities of Phytochemicals Againts Multidrug Resistant Bacteria and Biofilms. Natural Product Reports. 26, 746-757 
Versteegh J.K . 2012. Tumbuhan Berkhasiat Indonesia Edisi Revisi. alih bahasa. Soegiri. J, Nawangsari, IPB Press, Bogor.

Warsa, U,C. 2014. Buku ajar mikrobiologi kedokteran, Edisi Revisi. UI Press, jakarta

Waluyo L., 2008. Teknik dan Metode Dasar Dalam Mikrobiologi.Universitas Muhamadiah Malang. Malang

Widyaningrum, H. 2011. Kitab Tanaman Obat Nusantara. Penerbit Medpress : Yogyakarta

Wijayakusuma, H., 2012. Tumbuhan Berkhasiat Obat Indonesia. Seri Rempah, Rimpang, dan Umbi, Cetakan Pertama Pnerbit PT. Dytama Milenia, Jakarta. 